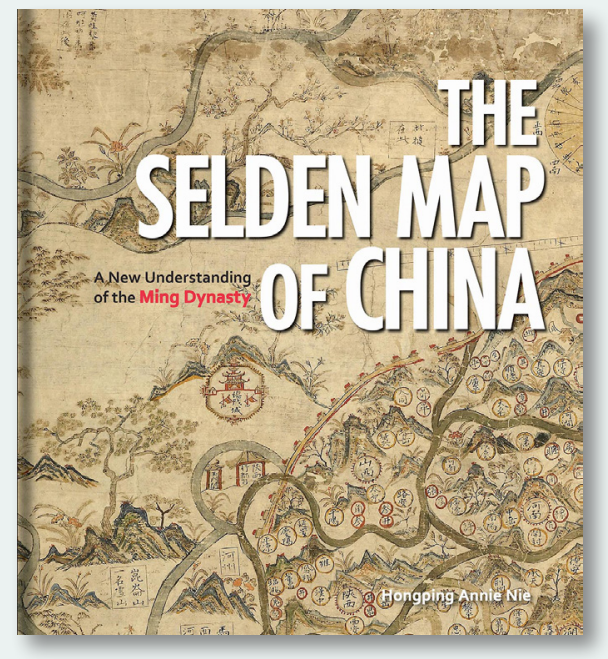

\title{
THE SELDEN MAP OF CHINA: A NEW UNDERSTANDING OF THE MING DYNASTY
}

By Hongping Annie Nie

Bodleian Library, 2019

74 pages

Hardcover: \$30.00, ISBN 978-1-85124-524-6

Review by: Glenn O. Humphress, Southeast Community College

In I659, A MAP of EAst Asia was added to Oxford University's Bodleian Library as part of a donation from the estate of English lawyer John Selden (1584-1654). The map had no title and has come to be commonly called either the Selden Map of China or the Nautical Chart of the Eastern and Western Seas by Western scholars and Chinese scholars, respectively. Largely forgotten over the subsequent centuries, the "rediscovery" of the map in 2008 has resulted in several publications about it and what it indicates about Chinese relations with other parts of Asia during the Ming Dynasty.

One such publication is Hongping Annie Nie's The Selden Map of China: A New Understanding of the Ming Dynasty (2019). Unlike its predecessors-Timothy Brook's $M r$. Selden's Map of China (2013) and Robert Batchelor's London: The Selden Map and the Making of a Global City, 1549-1689 (2014) — the major focus of this brief but beautifully illustrated book is on the map itself as a library artifact and work of art, rather than on the time period in which the map was painted. The book is divided into five chapters, albeit without any kind of preface or introduction. The first, "A Discovery in the Library," begins with the now relatively well-known story of Robert Batchelor visiting the Bodleian Library to examine what was listed as a Chinese map from the Ming dynasty, and recognizing it as primarily a merchant nautical chart unlike any contemporary Chinese map he had seen before. Instead of a traditional, China-centered map that fit the impression of a solely inward-looking Ming China, the Selden map revealed seafaring routes used in trade with other parts of East and Southeast Asia, as well as descriptive text about how to reach as far west as the Persian Gulf and Red Sea. Batchelor's discovery had considerable impact on the reinterpretation of seventeenth-century Ming China's relationship with maritime travel and global trade. Nie does not end the story of the Selden map as a library document there, and this chapter also includes a brief discussion of the poor condition of the map when found by Batchelor, how it had been used and maintained by the library during its time there, and some details about the conservation program that was initiated after the recognition of its importance, along with pictures of conservation activities. I personally would have liked to have seen more on this important aspect of cartographic library work that is seldom mentioned when discussing maps in collections, but I appreciate that conservation received any coverage at all.

In the next chapter, "A Cartographic Work of Art," Nie generates a true appreciation of the cartographic, geographic, and artistic characteristics of the Selden map. The tone is set for the latter with the opening sentence, "The Selden map of China is a work of art, beautifully painted in multiple colours and black Chinese carbon ink" (9), while a few pages later Nie writes, "A nautical chart, the Selden map can also be appreciated as a beautiful landscape painting, a perfect combination of the two forms" (13). After stating its dimensions (158 by $96 \mathrm{~cm}$ ), Nie speculates on why it was painted in the first place: "It is too big to have been conveniently employed as a chart. 
Most likely it would have been used to decorate a wealthy merchant's house, hung on the wall as a display of its owner's maritime knowledge, connections and power" (9). It is that maritime knowledge that is so prominently on display in the map, and Nie details the differences between representations of geographic information about the interior mainland, and that about the coastal areas, seas, and islands. As someone with an interest in the historical geography of Okinawa (the largest of the Ryukyu Islands) and its connections to other parts of Asia, I found the discussion of the trade route between China and Ryukyu, as well as the representations of compass bearings along that route, particularly interesting. Ironically, by the time the Selden map was produced, Okinawa's centuries-old trade and diplomatic relations with China were experiencing a decline due to increased influence of Japan, culminating in the Japanese occupation of the Ryukyu islands in 1609. Nie also explores how the Selden map fits into both Chinese and Western cartographic traditions, comparing it to examples of fifteenth- through seventeenth-century maps from both traditions that cover roughly the same geographic area. While placing the Selden map firmly within Chinese cartographic tradition, Nie notes that the very fact that the contemporary European presence in Asia is recorded on the map allows for the possibility that the cartographer may have been able to consult Western maps or charts that may have influenced the design of the map produced. In depicting both historical features-such as the sea route to the Ryukyu Islands-and contemporary features - such as the early European presence in Asiathe Selden map reflects a transitional period in the human geography of the region.

The third chapter turns more fully to "The History of the Selden Map." Since nothing is known about the cartographer, or of the map's history in China, this part of the story is restricted to listing various ideas about when and where it was produced and from where the cartographer may have come. Equally unknown and speculated upon is how the map got to England. Any certainty in the map's history does not begin until it is in the possession of John Selden, a "London lawyer and Oriental scholar" with an interest in "maritime rights and trade" (29). After Selden's death in 1654 the map was given to the Bodleian per a request in Selden's will that it be donated to a public library. The remainder of this brief chapter describes certain documented uses of the map at the Bodleian, primarily in the late 1600 s.

The remaining two chapters provide context for the Selden map. "Ming Dynasty Maritime Trade" provides a historical geography of Chinese maritime activities and trade from the mid-fourteenth century through the mid-eighteenth century, while "A New Understanding of the Ming Dynasty" describes the current understanding of the impacts of maritime trade on Ming China. These two chapters tread the more familiar territory covered by the Brook and Batchelor books, among others cited, and the Selden map gets almost no mention until the end of the last chapter. This reliance on other sources, most of which pre-date the rediscovery of the Selden map, creates a bit of a disconnect from Nie's final paragraph, which begins "The Selden map of China has changed forever the world's understanding of Ming China" (64). Without an integration of the material from the first three chapters with the material from the last two, the Selden map comes across as just one of many pieces of the puzzle, an important illustration providing a visualization of what other evidence already supports.

The common admonition that a reviewer should review a book on the basis of the author's intentions, rather than the book the reviewer wishes had been written, is complicated in this case by the lack of any introductory statement of what were the author's goals for the book. Thus, I find myself wishing for more of the three chapters about the map and better integration of that material with the two context chapters, while recognizing that neither of my wishes may have been a goal for the author. Ultimately, though, I think the strengths of this thin, richly illustrated book outweigh the organizational concerns of a cartophile writing a review for a cartographic journal. Nie's book celebrates the Selden map of China, and I wish we had more books like it celebrating more maps. 